\title{
THE PLACE OF THE COMMONS IS THE SQUARE
}

\section{Ruud Kaulingfreks}

University of Humanistic Studies

Utrecht, The Netherlands

\section{Femke Kaulingfreks}

University of Humanistic Studies

Utrecht, The Netherlands

\begin{abstract}
Squares are a distinctive fixture of a city. They form the centre of gravity of urban live and have been of paramount importance for social interaction through all cultures and in all centuries. The square is the centre of attention of every urban agglomeration. It's the spot where people gather and where commonality takes place. Squares are important as a place where the social is geographically embodied, as the space of the commons. They are the spot for sense, the space where sense making take place and where the social is constituted. Democracy was born on the square and they still are the place of politics. They are literally a place. In order to be the place of sense making, squares have to be empty; they are an expanse without artefacts. It's the emptiness of the square that makes them so suitable for social meaning. A plain surrounded by a maze of street and alleys so that the difference between the environment and the place enhance the openness of the square. In order to support meaning the square has certain specific features. One of them is the light. Everyone is in the same light in a square and therefore can see each other. The emptiness of the square makes a horizontal gaze possible where everyone is equal. There are no vantage points to observe the crowd. Architectural elements underline the equality and safety of the place. A square needs to be a safe place where one feels at home and not be disoriented by the emptiness. This essentially equalitarian and meaningfulness of the square has made the place also a place for contestation. All kind of different powers have colonized the square; the church, the king, the merchants, the state, the corporations. They all have changed the design of the square and tried to impose themselves on the openness. As a place of meaning the square is also a place of contestation between the commons and the powers. It has a long tradition of riots and occupation. It is the place where the people rise against the powerful. Of course it has also a long history of repression. Specific design aids to make sure the square can't be used as a meaningful and common place. Squares embody communality and meaning by allowing multiplicity and what Nancy calls being singular plural. They are the space of the multitude. Attempts to design, organize, plan the square close the multiplicity down to singularities with specific functions and deny the square of its meaningfulness. The square is then the geographical space for meaningful politics and for the commons.
\end{abstract}

\section{Keywords}

Place. Space of the commons. 


\section{PRAÇAS, LUGARES, COMMONS E ORGANIZAÇÕES}

\section{Resumo}

Praças são um elemento distintivo de uma cidade. Eles formam o centro de gravidade de vida urbana e têm sido de suma importância para a interação social através de todas as culturas e em todos os séculos. A praça é o centro da atenção de cada aglomeração urbana. É o local onde as pessoas se reúnem e onde a comunalidade ocorre. Praças são importantes como um lugar onde o social é geograficamente incorporado, como o espaço dos comuns. Elas são o local para sentido, o espaço onde fazer sentido tem lugar e onde o social é constituído.A democracia nasceu na praça e elas ainda são o lugar da política. Elas são, literalmente, um lugar. A fim de ser o lugar de fazer sentido, praças tem que estar vazias; eles são uma extensão sem artefatos. É o vazio da praça que as torna tão adequadas para significado social.Uma planície cercada por um labirinto de ruas e becos de modo que a diferença entre o ambiente e o local aumentam a abertura da praça. A fim de apoiar o que significa que a praça tem certas características específicas. Um deles é a luz. Todo mundo está na mesma luz em uma praça e, portanto, podem ver uns aos outros. O vazio da praça torna um olhar horizontal possível, onde todos são iguais. Não há pontos de vantagem para observar a multidão. elementos arquitetônicos sublinham a igualdade e segurança do local. Um quadrado tem de ser um lugar seguro onde se sente em casa e não se fica desorientado pelo vazio. Isto torna a praça essencialmente igualitária e também um lugar para contestação. Todo o tipo de diferentes poderes colonizaram a praça; a igreja, o rei, os comerciantes, o Estado, as corporações. Todos eles mudaram o desenho da praça e tentaram impor-se sobre a abertura. Como um lugar de significado a praça é também um lugar de contestação entre os comuns e os poderes. Ele tem uma longa tradição de revoltas e ocupação. É o lugar onde as pessoas se levantam contra os poderosos. Claro que também tem uma longa história de repressão. O desenho específico ajuda a garantir que a praça não pode ser usada como um lugar significativo e comum. Quadrados incorporam comunalidade e significado, permitindo que a multiplicidade e que Nancy chama de singular plural. Elas são o espaço da multidão. As tentativas de desenhar, organizar, planejar a praça fecham a multiplicidade até singularidades com funções específicas e negam a praça a sua significação. A praça é então o espaço geográfico para significados políticos e para os bens comuns.

\section{Palavras-chave}

Praça. Espaço comum.

\section{INTRODUCTION}

Squares have always been a distinctive feature of the city. They form the center of gravity of urban life and have been of paramount importance for social interaction throughout different times and cultures. As Cutini states: "A square is a public open living space, the meeting and relation space par excellence, where people do meet and gather day by day..."(2014, p. 248). Cutini explains that in the Italian language various expressions evoke the square as a symbol for the people. "To go down to the square" means to revolt, and "to listen to the square" means to sound out public opinion; thus even in everyday speech the square becomes 'the physical representation of its community meaning' (ibid.). The square is the place where public life is concentrated and 
social value is created. All kinds of encounters can happen on the square at the same time. It is the place to dwell, to meet, to discuss, to buy, to protest, to feast, to watch a spectacle, to be lazy, to flirt, to drink, to play etc. It can simultaneously be a place of contestation and transformation; a place where institutions are confronted, new forms of organizing emerge and hierarchical power structures are rearranged. The square has this potential because it is an open space in the city, which is inherently undefined. The square is an empty place, a white spot on the map, simultaneously incorporating all colors. It is therefore a place where anything can happen and anybody can reside. Its multipurposeness is what makes the square a common place for everybody, and therefore a place where a sense of community can arise. Squares embody communality. They are the locality of the commons and represent a space that cannot be exclusively appropriated because this space is open to the public. In this paper we want to demonstrate the openness of the square as an embodiment of the commons. The spatial features of the square make it inviting for a variety of people and activities. Squares allow a multiplicity of manifestations of togetherness, without being forced into one common denominator. They are the place to be singular-plural, in the words of Jean Luc Nancy (2000). The square allows for the emergence of spontaneous communities that display an awareness of common interests. Our analysis of the square as the place for community focuses mainly on the writings of Jean Luc Nancy since, according to us, he presents a novel way of analysing the social that is particularly of interest when dealing with pluriformity. As locality of the commons, the square also attracts protest. Besides being the place of fairs and festival, squares all over the world have a history of protest and repression. Our analysis of the square therefore implies an analysis of the struggle between attempts to control the square and the contestation of the powerless. Over the recent years we have seen a rise of protests against anti-democratic, neoliberal and capitalist economic structures and political governance, which were all characterized by gatherings on the square as focal points (DHALIWAL, 2012; SCHIFFMAN et al., 2012; LOPES DE SOUZA, LIPIETZ, 2011; STAVRIDES, 2012; MAROM, 2013; ÖRS, 2014). On the square, people experiment with new forms of real and direct democracy, in which the concept of the commons is actualized.

\section{AN OPEN SPACE IN THE CITY}


When wandering through a city, one often ends up at a square. Sometimes accidentally, but very often intentionally, since cities are largely known by its squares (CUTINI 2014, p. 48). It seems like all streets lead to this open space. The square is a fissure in the city, where the dense construction of buildings cracks open (see for example Piazza del Campo in Sienna). In cities which are build according to an Italian Renaissance design, a main square is located right in the geometric center of the settlement, complemented by a number of smaller squares scattered around (CUTINI 2014, p. 253). "It is only when the main square of most old towns is reached that one has really 'arrived'; all the streets lead naturally to this focal point. The centre dominates the town in size and grandeur; it gives meaning to its existence as a place distinct from other places" (MOUGHTIN 2003, p. 90). Also in cities with a more modern urban design squares often form a central place for social interactions. These light and open spaces are attractive places to meet one another, since spatiality is an important aspect of social traffic. Interactions do not take place in a void. The topos where we meet, influences the character of the interaction. We therefore often try to choose a place that fits the encounter. Which interests play a part in the meeting? Who is allowed to set the parameters and who should adapt to the situation? Do we invite the other over to our terrain? Who is the guest and who is the host? Such questions are easily solved by the existence of public spaces where we can meet each other; neutral places which are not owned by anybody and therefore facilitate a more symmetrical relation. Squares are such places that can be temporarily used by everybody.

Although in English the name is 'square' - even when they obviously are not always square (for instance Times Square in New York) -, in almost every other Western language they are just called 'places'; Platz (Potzdammer Platz in Berlin) in German, plaza in Spanish (Plaza Mayor in Madrid), piazza in Italian (Piazza Navona in Rome). The Dutch word plein is derived from the Latin planum, or a flat space without any particular content (Het Plein in the Hague does not even need a specific name). Such an empty space can become a place in relation to its surroundings. As Heidegger explained, a place is the location of something; a thing, a person (1971, p. 141). It is a distinguishable position in the vastness of the world. A place indicates an opening in a labyrinth of possibilities. Heidegger gives the example of a bridge. Along the shores of the river many points could be indicated, which could be occupied by something. One of these points becomes a place because of the bridge; it becomes the place of the bridge. A place is a locality, which is opposed to the indistinctiveness of empty space. A place is always the 
place of something. Within the city the square indicates the place where community can be actualized. This locality allows for different kinds of use and different forms of appropriation by different people. Mattias Kärrholm (2005) speaks of territorial complexity which is generated on the square. Various groups of people develop a certain personal relationship with a place, because of the way they identify with and use this place. Simultaneously, top-down planned and impersonal territorial strategies take place in order to delimit or control a place. It is symptomatic that most redesigned modern squares are ordered in different spaces each with it's own purpose, even when they are designed for relaxation of the citizens, as is the case with numerous squares that have been reclaimed from traffic (See the seminal book by Gehl and Gamzoe; 2006). The interplay of various territorial tactics and strategies, formal and informal markings of a place, exercised by a variety of groups and actors, lead to a territorial complexity. Squares are characterized by a complex interplay of different uses and people. Other than for example shopping malls, which are regulated spaces designed with one form of use and activity in mind, there is not one territorial strategy dominating the square (KÄRRHOLM 2005, p. 16).

The empty space of the square becomes a locality because of the contrast with its surroundings. The large buildings around the square, including shops and café's with terraces, define the square, because they attract visitors (see the Grote Markt/Grand Place in Brussels). Hence, paradoxically enough, the limits to the open space of the square define its inviting character. The buildings around it guard the square and keep it together. An equilibrium is needed between the square and the adjoining urban texture. Urban designers have researched the ideal physical features of the public square, taking into account aspects such as solar access, wind flow, thermal comfort, noise and pedestrian movement (GIDDINGS; CHARLTON; HORNE, 2011). Architects have discovered that there is an ideal relation between the height of the surrounding buildings and the surface of the square (Moughtin 2003, p. 100). Unsurprisingly this relation is $1 / 3: 2 / 3$, or the Golden Ratio. If the adjacent buildings are too high, the square becomes pompous and authoritarian. It makes us feel small and insignificant (like on Potsdamer Platz in Berlin). If the surroundings are too open, the communal space becomes an anonymous place and agoraphobia is easily experienced (like on Plaza de la Revolucion in Havana). People get lost in the vastness of the space if there are no protecting boundaries (like on Praça dos Três Poderes in Brasilia). There is a delicate balance between a space that is open for everybody and a limitless, impersonal space. The former is cozy and invites to dwell in 
it. The latter scares and disorients us. The atmosphere of the square takes shape in interplay between the open space and the buildings on the periphery.

Early settlements generally had an open, common place in the closed, built environment. This common space was of great importance to protect the community. In walled cities, and even before that in the castle, there was an open space left within the tight fabric of buildings, where peasants and their animals could come inside and seek shelter in case of an attack. The inhabitants of the neighboring countryside were brought inside the walls when the enemy was approaching. Walled cities could not grow outside the walls so they expanded inside and became a dense maze. Every inch of the city was made of use. Despite the lack of space, some vast terrains remained unoccupied, in order to accommodate large crowds of people. In these places people gathered for common purposes. During the Middle Ages and the Renaissance squares were used for commercial purposes as market places, as well as for public festivities and executions. Also in modern cities squares function as traffic nodes and important public buildings are often grouped around the square (MOUGHTIN 2003, p. 93). The square forms a spatial opening where public encounters can take place, surrounded by the dense urban tissue of private places in streets and alleyways, nooks and crannies that can be easily appropriated. It is this contrast between the darkness and secrecy of the niches in between houses, and the wide openness and light of the square, that makes the square so attractive. In the square the gaze is free and horizontal. The square is therefore a place of light where one can see the other in reciprocity. There are no hiding places in the middle of the square and there are no vantage points where one can observe without being seen. In the square the gaze is democratic an egalitarian; it therefore contests power structures of discipline and control. As was explained by Foucault (1991) disciplinary power works through an asymmetric gaze, by seeing without being seen, and in this way attaining control over subjects which are exposed, while the center of power remains hidden. In contrast to such a hierarchical, asymmetric power production, on the square the power of the commons is exercised in the open horizontal gaze of the users of the square. Literally and physically, those who meet on the square stand on the same level, all exposed to each other. This horizontality and equality forms a crucial feature of the commons. The transition from the dark streets and allies to the light square marks a transition from power domination to the shared power of the commons. 


\section{THE PLACE OF THE COMMONS AND COMMUNITY}

One of the origins of squares is the commons, as a general place to meet, which is not owned by anyone in particular. The commons are aimed to be of use to as many people as possible without distinction or exclusion. In the Middle Ages the common fields where the herd of the whole village flocked and grazed had this function (COOP AND BRUNCKHORST, 1999). In an urban setting the square can have a similar function. The square brings people together and hence speaks of a communal economy; an economy of sharing instead of exclusive property. Since the square is of everybody, it is the free space where the community rules, instead of an individual owner. Here value is created through cooperation as well as collective use, and not through the competing trade of commodities. Even on the marketplace, each stall can be of private property, but all salesmen equally share the marketplace itself. The market itself is the embodiment of the commons. The square therefore offers space to a different kind of entrepreneurship, which is not based on the entitlements derived from private craftsmanship, but on the shared efforts of a community. On the square, one organizes collectively, while making use of shared resources and attaining to public regulations. The results of the enterprises undertaken on the square therefore benefit the community as a whole, and cannot be claimed by particular individuals or groups.

The square is never defined by one activity or by a selection of people with a particular identity. As an open space of the commons it is not uniform. It serves multiple purposes and its use changes continually. There is a thin but essential distinction between the square being of everyone or of nobody. The square itself is public and therefore it has no particular identity. Everyone can take the square, exactly because it belongs to nobody. It is nobody's home, but it can be a place where everybody feels at home. The square is communal but this does not mean it is a common denominator of sharing and feeling part of a group or club. In this sense the square could be seen as the place where community emerges, as envisioned by Jean-Luc Nancy. This community does not consist of the sum of autonomous individuals or subjects, but is the expression of an inherently shared being, which is always already singular-plural; not reducible to separately existing entities. It emerges spontaneously in encounters on the square, without a pre-meditated organization-model or identity. The square is a place where common meaning is created, 
while it constantly transforms with the present community. Because the square is not an inherently prescriptive place, it simultaneously opens up, and binds together.

For Nancy, the concept of community does not indicate a homogeneous entity. Our sense of community rather originates in a shared co-existence in the world, which happens unexpectedly. Nancy emphasizes that everything that exists always exists together with something else. In existence, we therefore always share the world (ibid., 29). We are always already together with others. Even in the case in which we define ourselves as unique and autonomous subjects, we have to do this by distinguishing ourselves from others. Being therefore always takes place in diversity instead of unity. The "with" is therefore at the core of being itself. Being-with others is not a relation which is added up to an autonomous state of being-by itself, as the origin of being often tends to be understood according to Nancy (ibid., p. 30 - 31). Since being always means coexistence, we always already think and interact within a certain form of community. This notion of community should not be understood as a certain natural or original entity, which forms a certain foundation for social interactions and the political formation of a society, as one can find in romantic interpretations of Rousseauian ideas about a "natural community."

Such a thinking constitutes closure because it assigns to community a common being, whereas community is a matter of something quite different, namely, of existence inasmuch as it is in common, but without letting itself be absorbed into a common substance. Being in common has nothing to do with communion, with fusion into a body, into a unique and ultimate identity that would no longer be exposed. Being in common means, to the contrary, no longer having, in any form, in any empirical or ideal place, such a substantial identity, and sharing this (narcissistic) "lack of identity." (NANCY 1991, p. 38)

The feeling of "loss of communitarian intimacy" plays an important role in our historical understanding of the relation between community and society, according to Nancy $(1991,9)$. Where society is a construct in order to deal with political interests, as "a simple association and division of forces and needs," community is seen as a pure body in which people are bound together by sincere intimacy and harmonious relations (ibid.). In contrast to this romantic notion of community, Nancy understands community as essentially ungrounded in its lack of identity. We do not produce community, as if it were a piece of work, an opus, but we rather experience it in its "inoperativeness," or its unworking impact (NANCY 1991, p. 31). Community simply "happens to us in the wake of society", neither as a pure form of shared intimacy, nor as a deliberately constructed 
agreement (ibid., p. 11). Nevertheless, this sense of community, which can spontaneously emerge on the square, can move people to act out politically, and strive for the transformation of society.

For Nancy, a sense of community and a sense of the political are inextricably bound to each other. "...: the political is the place where community as such is brought into play" (NANCY 1991, p. 37). However, just like Nancy associates an inherent lack of identity to community, political agency is also not based on a pre-established, strong subjectivity or ideology in his interpretation. The political is not based on a shared organization, program or identity which brings individuals together in a collective body, but on the understanding that we necessarily coexist with others with whom we share no necessary similarities. Political agency is not an act of formation of a people around a specific programmatic claim, but rather the initial affirmation of the equality of all in an irreducible difference. For Nancy, political agency begins with the awareness that we share the world on an equal ontological basis. This initial state of being is the only state of being in which we are together on a completely equal basis. An experience of the commons can highlight this ontological equality.

Nancy is interested in the conception of the "commons" as a drive for political agency, and traces the origin of this notion back to the cloisters/monasteries of the 14th century. The monastery used to be in the first place the communal possession of the community of monks, before individual monks could claim part of this possession on the basis of their membership of the monastic order to which the cloister pertained. Since that period the notion of the commons is used to speak of the collective possessions of a community apart from its individual members. The commons imply a shared coexistence that precedes individual claims to ownership, identity or governance. This understanding of commons becomes relevant for political agency when it enables us to say "we" without implicitly indicating a shared political program, a shared national character, or a shared citizenship status. Nancy speaks of an experience of the commons that can literally open space between people, without becoming a fixed ideology or designed blueprint for society. The space that is opened between people can enable us to ask questions like: "How can we think about society, government, law, not with the aim of achieving the cum, the common, but only in the hope of letting it come and taking its own chance, its own possibility of making sense." 
We can encounter others, who live fundamentally different lives, at a specific place where we share a certain situation that suddenly makes us aware of the fact that we are part of the same world. Such an encounter can inspire collective political agency, and usually takes place in public space. The public nature of the square, in contrast to places of private ownership has such political implications. Traditionally, the square is therefore the designated place for the self-governance of the people. The agora is the birthplace of democracy in ancient Greece, the square where citizens gathered to discuss the matters of the polis. It is the place where general interests are defined and served. On the ancient Greek agora a form of direct democracy was performed by all men with citizenship rights. Today the square still functions as the place where people go to claim direct influence on matters of governance. It is no longer a place where those with exclusive citizenship rights can raise their voice, but also for those who are not treated as equal citizens, and hence wish to claim their rights. Contestation against state authorities that are not correctly representing the people often takes place on the square. David Harvey emphasizes the intimate relation between the city and citizenship (2012, p. 32). The central squares of cities can turn into heterotopic spaces in the Lefebvrian sense. In such spaces a radically different political organization can be imagined and carried out. They are the social spaces where disparate groups can come together in a spontaneous moment of irruption, to engage in collective action (ibid.).

\section{COLONIZATION ON THE SQUARE}

The spontaneous community formation on squares is difficult to manage. Historically squares have been considered dangerous meeting places for the people by institutional and governing powers. The physical assembling of large numbers of people in public space has proven to be an effective method to pressure state powers by those who cannot make use of institutional infrastructures. 'One means by which insurgent groups overcome their general inferiority in resources is to take advantage of one resource they have - the force of numbers' (SEWELL, 2001, p. 58). Squares therefore have a long history of colonization. From the borders of the square, governing powers can cast a hidden gaze on the crowds on the open plane, and hence exercise a form of control. Different powers have tried to gain control over the commons by building big structures overlooking the square. These are vantage points as Dale and Burrell have clearly 
explained (2008, 43 a.f.). According to them the domination of the skyline is equated to the domination of markets and of economic competition (ibid., p. 49). Architecture is used by political leaders to seduce, to impress and to intimidate (ibid., p. 43). Dale and Burrell analyze the Vasari corridor in Florence as a typical example of architecture that separates and divides. "It provides a superior route between office, church, garden and home for the powerful, whilst separating them physically and symbolically from the general populace below" (ibid., p. 170).

Historically, within an urban environment influenced by Christianity, the church arrived first on the square. A cathedral dominates many squares. It is important to note here that the square existed before the church. Originally churches had no open space in front of them. Houses were built leaning against the church, using the church walls as props, like we still can see in the case of several Middle Aged churches (see for instance Santa Maria del Mar church in Barcelona). Later, churches were built next to squares, where large crowds of people could gather for religious ceremonies. The common space became a semi-sacral space, where the community stood in the shadow of the church. The square became the outside portal of the cathedral, where one could admire its splendor from a distance. After the church the king - and later the state - built palaces opposite the church, thus making the square a front yard for the home of governing authorities (see Piaza della Signoria in Florence). The square was transformed into a place to hold military exercises, hence the Spanish common name plaza de armas, which can be found in several Latin American capitals (in Santiago de Chile, Lima and Havana for example). The crowds could thus be controlled by the military, as directed from the palace.

Another colonization of the square is exercised by commerce. Warehouses and palaces of rich merchants were built around the square in order to keep an eye on the market during the European Renaissance. In present times we see that banks and corporations took over the squares and preside very distinctively over the communal space, privatizing it and transforming the social into a consumers space where one has to comply with the regulation of the owner (Potzdamer Platz in Berlin is dominated by banks since it was remodelled in the '90s). Café's and terraces claim a monopoly on the way one is supposed to spend time on the square (KOHN 2004). The same generic Starbucks cafés emerge everywhere and in many squares one is no longer allowed to eat ones own food or exercise ones own activities. The privatization of public space has enhanced the commodification of the city, where nowadays commercial activities are favored over other social forms of gathering. Investors as well as local authorities generate profit and 
income from the privatization of public space through the taxation of space and the arrival of private enterprises. In order to minimize the risk of unmanaged gatherings on the square, access is regulated and social control is enhanced through privately owned urban development projects (MINTON, 2006).

In sum, the square is overlooked and controlled by the church, the government, the bank and (partially) filled with terraces (A nice example is the Zocalo in Mexico City, with the cathedral, the presidential palace and the central bank all around the same square). However, this colonization is never complete. The square still attracts spontaneously emerging communities, which often directly oppose the colonizing powers on the square. Squares are not politically innocent. Since squares are the place where social value arises and the public interest is defined, they are also the place of protest against dominant powers and discontent with existing injustices and inequalities (ÖRS 2014, p. 492). Uprisings often take place on the square. They still remain the place to meet and discuss for the ones who are not allowed inside the palace and are confined to speak from outside (like the name of the Piazza del Popolo in Rome suggests).

\section{CONTESTATION ON THE SQUARE}

The revolution often starts on the square, because it is the symbolic place of the people and of democracy, the governing power of the people. It is remarkable that even when squares have been transformed into anonymous places because they are for example too large and open, as in the case of Tiananmen square in Beijing, or because the open space is asphyxiating with traffic, as in the case of Tahrir square in Cairo, they still attract protestors and uprisings. Both places incidentally are the places where a revolution started. Mao opened the doors of the Forbidden City (and after the revolution built the headquarters of the Central Committee on the square) and the Egyptian Independence was proclaimed at Tahrir Square (and where now is the headquarters of the republican party). The spatial features of the square have facilitated this symbolic political function. Both places were first 'desacralized' before they were 'resacralized' in the name of the people, as Sewell states (66). Tiananmen square, for example, was a place of vertical communication between the Communist Party leadership and the anonymous masses, before it was reclaimed as a space of horizontal self-governance during the student uprising. However, their attempt at giving the square a new meaning was eventually 
violently oppressed by the authorities. According to Sewell, the authorities' fear of the symbolic power of the square is a reason why it is no longer used for official, ceremonial gatherings, now mostly attracting foreign visitors (ibid.).

The square remains 'a locality', an open space where horizontality reigns, despite attempts of a vertical gaze of power to colonize the square. The square is thus the appropriate place where sparks of a sense of the commons and of political change are ignited. We have seen this potential in recent events of protest, which all took place on and around squares. The occupation of squares in the context of the Indignado movement, the Arab Spring, Occupy and the Gezi park movement differ from the traditional occupation of squares by the centers of power such as the church, the army, the crown, the state or the stock exchange, because they create space and visibility for the commitment to the commons of ordinary people. The Gezi Park protests in Istanbul largely took place on Taksim Square, bordering the park that the protesters intended to protect against demolition (ÖRS, 2014, p. 492 - 496). Symbolically, this square was initially constructed on a vast plain where army barracks were located during the Ottoman Empire. Protests arose when the currently ruling AKP party attempted to impose a certain neo-Ottoman identity on the square with a large scale redevelopment project. The protesters envisioned a more inclusive urban landscape and republican imagination (ibid., p. 497). Similarly, Smithsimon (2012) states that the occupation of Zuccotti Park during Occupy Wall Street did not only take place in reaction to the economic crisis, but also in reaction to the extensive segregation and policing of public space in New York city. Due to gentrification, public plazas were increasingly designated for the richer segments of the population. Stop and frisk tactics by the police filtered undesired bodies out of public space. The Occupy Movement re-opened public space to a wider variety of people. A similar re-appropriation of public space for a wider community formation took place during the occupation of Syntagma Square in Greece. 'Communities create "common space", space used under conditions decided on by communities and open to everyone. (...) The community is formed, developed, and reproduced through practices focused on common space. To generalize this principle: the community is developed through communing, through acts and forms of organization oriented toward the production of the common' (STAVRIDES, 2012, p. 558). In this way, the square can form a starting point for solidarity, for political alternatives.

A distinctive quality of the recent protests in squares, underlining the communality of the space and a re-appropriation of the public space, is the absence of specific 
leadership. All examples of recent protest movements that gathered on squares refused to be represented by a single political organization, defining its program or mode of communication. These movements were characterized by their leaderless organization structure and emerged outside of the existing networks of civil society organizations such as NGO's and trade unions, as well as political parties (ISHKANIAN; GLASIUS; ALI, 2013). While the space of the square is occupied, the event of the protest is not claimed by a specific institution, party or organization. No one can exclusively appropriate the expressed critique on existing political and economic governance, which is seen as already for too long framed in exclusive and exclusionary terms.

These occupations and expressions of contestation on the square were performed by a multitude that based a "we" not on a shared ethnicity, nationality, citizenship status or ideology, but on a sharing of the same world at ontological level, like Nancy envisions it. This multitude cannot be theorized as one social movement. In new social movement theory an emphasis is placed on identity claims, which are enforced in order to plead for equal rights for deviant groups. The struggle of new social movements no longer only takes place in the area of the class struggle, but it also addresses social exchange and cultural production (MELUCCI, 1996). The feminist movement, environmental movement and civil rights movements, to name a few well-known examples, resort to a shared culture and collective identities in order to push for political change (CASTELLS, 2009). This emphasis on a shared culture and identity, which provides a shared meaning and position to the movement, is absent in the coming together of multitudes on a square. This became clear in the case of the Occupy Movement, for example. The slogan "We are the $99 \%$ " was widely used in the Occupy Movement. It indicated that the only antagonistic division between friend and enemy was drawn between an elite one per cent, unjustly possessing most political and economic power, and a highly diverse multitude of $99 \%$, with highly divergent backgrounds and cultures, but equally suffering from the economic crisis and lack of political influence.

We are the 99\%" highlights a division and a gap, the gap between the wealth of the top $1 \%$ and the rest of us. As it mobilizes the gap between the $1 \%$ with half the country's wealth and the other $99 \%$ of the population, the slogan asserts a collectivity. It does not unify this collectivity under a substantial identity-race, ethnicity, religion, nationality. Rather it asserts it as the "we" of a divided people, the people divided between expropriators and expropriated. (DEAN, 2011) 
The multitude does collectively contest injustices and unequal treatment, but not on the basis of a shared culture or identity (STAVRIDES, 2012, p. 592 - 593). It rather comes together on the bases of a shared, yet heterogeneous perspective on agency. Other than the undifferentiated unity of the masses, the multitude is composed of a set of singularities, whose difference cannot be reduced to sameness (HARDT; NEGRI, 2004, p. 99). Community formation, like Nancy and Hardt and Negri understand it, happens in a being-together in the world with others who can be radically different from us. The inherent confrontation with difference does not always lead to recognition and consensus, but also entails insecurity and an ongoing discussion of societies features and foundations (KAIKAS; KARALIOTAS, 2014). Such continuous questioning of fixed foundations can be found in the political agency that was recently developed, and continues to be developed on squares all over the world. The recent political protests that take place on squares are all criticizing dominant power structures that keep deep inequalities between economic and social elites and marginalized groups in place. They criticize the dominant status quo of neoliberal governance and capitalist economy. Because capitalism is not based on commonality, but on the individual I, and on ownership in the material sense, instead of ownership as a sense of self or singularity which is always co-shaped by others. In contrast to these existing power structures, squares offer a place to experiment with political agency, which is based on a notion of the commons. The multitude can act politically, not because it stands as one or has one identity, but because in its internal diversity, it also has a longing for a more just and egalitarian governance in common.

David Harvey speaks in this sense of the creation of a 'political commons' in a central public space, 'a place for open discussion and debate over what that power is doing and how best to oppose its reach' (2012, p. 161). In reference to various recent protest movements that occupied public squares, Harvey states that the collective power of bodies in public space is still the most effective instrument of opposition when all other means of access are blocked (2012, p. 161 - 162). Dhaliwal emphasizes the same physical occupation of the square with an encampment as an important strategy of resistance in the Spanish Indignado movement (2012). This strategy was inspired by the somewhat earlier occupation of Tahrir Square during the Arab Spring. The occupation of Tahrir Square enabled previously dispersed groups of protesters against the Mubarak regime to gain larger visibility and a central, easily accessible place to coordinate their actions. Patel (2013) hypothesizes that the strategies of resistance as applied on Tahrir square particularly inspired protests in cities where a large, focal square could be occupied, as 
was the case in Madrid and Barcelona where the Indignados Movement was attracting large crowds of people. New spatial relations were created on the square, by introducing mass public deliberation and horizontal decision making in general assemblies, as opposed to the dominant and hierarchical structure of the existing political order. However, this enactment of a different form of political decision making on the square was of a temporary nature. Eventually the camp on the square was evicted due to a combination of police repression and the need for people to focus on their lives outside of the square. An attempt was made to continue mobilization through neighborhood assemblies, but the question remains what sustainable effect could be expected from the efforts of movements such as the Indignado movement. Nevertheless, this question might not be the most important question to ask in relation to protests that evoke the creation of a political commons. They enunciate the possibility of different social relations and forms of decision making, which can inspire new political practices in other settings, beyond the temporary occupation of the square (ibid., p. 263).

\section{REAL AND DIRECT DEMOCRACY}

One of the most remarkable aspects of the Occupy Wall Street movement (OWS) is its capacity to ground itself in a struggle for a public commons. For many involved, including myself, Zuccotti Park was our public commons, our agora, just as the gardens in Union Square have been for so many years in New York. "The agora was the center of athletic, artistic, spiritual, and political life of the city", notes OWS activist Morgan Jenness. Yet, today, many suffer from "agoraphobia... a fear of participating as a full citizen in the commons," she continues. OWS challenged this logic, grounding itself in the public commons from the movement's very first day. (SHEPARD, 2012, p. 21).

The movements which ask for "real democracy" and oppose themselves to human indignation offer space to organize a variety of activities in the square, in which anyone can take part at any time, thus creating a constantly evolving form of organizing, in which the one person can take the place of the other according to the flow of events. People continue to find inspiration in places where one can transform from a random passer-by to a participant of a general assembly, while simultaneously children are playing in an area of political protest, people do gardening, read books and discuss the latest sports results on the streets, and the energy of tense confrontation and liberation ebb en flow like the tides, everything constantly moving and transforming. Many of the protests on 
squares take place in election time, showing other expressions of political engagement, which form an alternative to voting. The communities that gather on the square develop decentralized and open-ended network structures, which they use as a basis for decisionmaking. Practices of participatory and consensus-based decision-making and horizontality characterize their way of organizing. In doing so, the protesters open up the possibility for a much more diverse and inclusive practice of democracy in which conflicting identities and opinions flourish, rather than the existing systems of liberal representative democracy (MAECKLERBERGH, 2014, p. 347). The political agency on the square takes place here and now, and is an expression of direct democracy, in contrast to the procedures of a representative political system. Swyngedouw emphasizes that this agency does not articulate specific social or economic demands directed at the elites, but aims at a revisiting of the nature of 'the political' (2014, p. 123). They can take a peaceful or militant form, but are in general directly opposed to the rules and regulations of institutionalized security system, which prohibits large gatherings in public space. In a political moment public space can be reclaimed from such regulations. 'The space of the political is to disturb the socio-spatial ordering by re-arranging it with those who stand in for "the people" or the community' (SWYNGEDOUW, 2014, p. 132). Such events of protest should not directly be judged on their demonstrable long-term 'outcomes' with respect to institutional structures. They rather have a value as "prefigurative politics", as 'a practice, movement, moment or development in which certain political ideals are experimentally actualized in the 'here and now', rather than hoped to be realized in a distant future' (VAN DE SANDE, 2013, p. 230). Movements of prefigurative politics do not see it as their highest goal to assume durable state power, but rather exhibit an alternative, horizontal community formation (DHALIWAL, 2012 p. 268). Stavrides states that the common space which is opened up in such movements indicate a threshold to new possibilities, because they are not 'demarcated by defining parimeters' (2012, p. 589).

Uruguayan journalist and writer Eduardo Galeano nicely captured this kind of movement into words, while standing on the Plaza de Catalunya in Barcelona during the Indignado occupation. For him, the enthusiasm that is generated in the occupation of squares is its most important effect. He indicated the Greek origin of the word enthusiasm, which means to have the Gods inside. Enthusiasm makes us experience the intrinsic value of life, which we should not allow to be devaluated by indignant political or economic management. According to Galeano we currently live in an uninspired world, but the 
young people he saw around him during the occupation of Plaza de Catalunya showed him that we could look beyond the threshold of this world, towards new perspectives. This opening of a window to another possible world is more important to Galeano than the question to which concrete institutional changes the protests and occupation of squares will lead. It interests him what happens in this moment, a moment in which an endless range of possibilities is announced. When we truly experience love, we truly feel that we are alive and we no longer think about dying, as Galeano says. Love is endless in the moment we experience it, as long as it lasts. This experience indicates a calculation of time other than the checks and balances that are made in the context of economic efficiency, a political system that is defined by the calculation of profit and loss. The square can thus be the place where the spark for political practices alternative to the capitalist and neoliberal hegemony is ignited.

Galeano's interpretation of the events of protest on the square echoes Nancy's understanding of how unexpected events can contribute to opening up of another world. Our co-appearance in the world is characterized by Nancy as an event (NANCY; BAILLY, 1991 p. 8). This event cannot be grasped in a modus of thought or speech. "The event surprises or else it is not an event," as Nancy states (2001, p. 167). The event-ness of the event can therefore never be captured in our thoughts or expectations. The meaning of the world emerges together with us in this event, and is therefore not external to this world (NANCY, 2007, p. 43). The event is not "what is produced or could be shown" as the outcome, or even the entry, of guided human interactions, but rather the very happening of the unexpected (ibid., p. 169). This also implies that there is not only one ideal world, but a "multiplicity of worlds" (NANCY, 2007, p. 109). No first origin can be designated as the point out of which the world emerged. There is nothing other than the "happening" of the world itself that takes place in each instant, in each situation. As such, the world itself is also no "effect of some particular operation of production," but it “springs from all sides" (NANCY, 2001, p. 83).

The fact that there are more worlds possible also opens the possibility of disagreeing with the one in which we find ourselves and engage in a struggle to improve it. It is precisely the recognition that no blueprint for the world can be made which can form the basis for a struggle against injustices created by an ordering of the world which pretends to assign people to unequal, but seemingly natural positions. A single "true" arrangement of the world would be a foundational illusion with the unjust pretention to generate order. 
To create the world means: immediately, without delay, reopening each possible struggle for a world, that is, for what must form the contrary of a global injustice against the background of general equivalence. But this means to conduct this struggle precisely in the name of the fact that this world is coming out of nothing, that there is nothing before it and that it is without models, without principle and without given end, and that it is precisely what forms the justice and the meaning of a world. (NANCY, 2007, p. 54 - 55).

Squares are the quintessential public space and the place where a sense of the commons is created and reinforced. We intend to show that the commons are grounded in the open, empty and horizontal spatiality of the square. Everybody can be equal on the square. Pluriform and spontaneous communities emerge in this place, inciting a solidarity based on new possibilities for a shared political agency, instead of a shared identity or culture. As the place of the commons squares are the privileged places to oppose the powers that be and to imagine new worlds, as was put forth by Galeano. Politics is not only a matter of ideas and discussions; it is also a matter of space and locality. The square is an actor in the making, bringing large numbers of people together, enforcing social meaning and enabling the literal 'taking place' of protest. On the square resistance of control as well as a sense of togetherness is embedded that can take many forms. The square is the stage of society. It materializes a being in common that is not planned of designed other than being a place in the full meaning of the word.

\section{CODA}

Flemish writer Paul van Ostaijen wrote the short story "The City of Constructors" (De stad der opbouwers) (in Music Hall, 1916). It is the story of the city of Creixcroll where the mayor has decided that demolishing buildings is too easy and morally wrong. It is therefore forbidden to tear anything down and citizens are encourage to build as much as possible. A building fever takes hold of the city. Everybody starts constructing new buildings. Soon there is no more space available for new buildings and the people cannot continue to build into the heights. Consequently, the squares are all abolished and filled with buildings. This is not to everybody's liking and an anti building movement arises. The leader of the movement is promptly arrested and sentenced to the pillory in order to set an example to anyone wishing to tear a construction down. His sentencing also forms an excellent opportunity to have a festival. However, the executioner notifies the judge 
that this is impossible since there are no squares any more and hence no place for the pillory and festivities. As soon as the people hear of this outcome they rebel, since they are longing for festivities. The city council is expelled and the leader of the anti building movement is freed and named the new mayor. In his first speech standing on the balcony of the city hall he asks the people: "What do the people want?" "Squares!" they respond in unison.

\section{REFERENCES}

CASTELLS, M. The power of identity: the information age: economy, society and culture. Londres: Wiley-Blackwell, 2009. 2 v.

COOP, P.; BRUNCKHORST, D. Triumph of the commons: age-old participatory practices provide lessons for institutional reform in the rural sector. Australasian Journal of Environmental Management, [s.1.], v. 6, n. 2, p.69-77, jan. 1999.

CUTINI, V. Spatial analysis of urban squares. Tema: Journal of Land Use, Mobility and Environment, [s.1.], p.247-258, 2014. Tema. Journal of Land Use, Mobility and Environment. Disponível em: 〈http://dx.doi.org/10.6092/1970-9870/2476>. Acesso em: 5 set. 2016.

DALE, K.; BURRELL, G. The spaces of organisation \& the organisation of space, Basingstoke: Palgrave, 2008.

DEAN, J. Claiming division, naming a wrong. Theory \& Event, [s.1.], v. 14, n. 4, 2011.

DHALIWAL, Puneet. Public squares and resistance: the politics of space in the Indignados movement. Interface: a journal for and about social movements, [s.1.], v. 4, n. 1, p.251-273, maio 2012.

FOUCAULT, M. Discipline and punish: the birth of the prison. Londres: Penguin, 1991.

GEHL, J.; GAMZOE, L. New city spaces. Copenhagen: The Danish Architectural Press, 2006.

GIDDINGS, Bob; CHARLTON, James; HORNE, Margaret. Public squares in European city centres. Urban Design International, [s.1.], v. 16, n. 3, p.202-212, 10 ago. 2011.

HARDT, M; NEGRI, A. Multitude. Londres: Penguin, 2004.

HARVEY, D. Rebel cities: from the right to the city to the urban revolution. London;New York: Verso, 2012.

HEIDEGGER, M. Building, dwelling thinking, In. Poetry, language, thought. Nova Iorque: HarperCollins, 1971. 
ISHKANIAN, A.; GLASIUS, M.; ALI, I. Reclaiming democracy in the square? Interpreting the Movements of 2011-2012, Report, London: the London School of Economics and Political Science, 2013.

KAIKA, M.; KARALIOTAS, L. The spatialization of democratic politics: Insights from Indignant Squares. European Urban and Regional Studies, [s.1.], p.1-15, 8 maio 2014.

KÄRRHOLM, M. Territorial complexity: a study of territoriality, materiality, and the use of three squares in Lund. Nordic Journal of Architectural Research, [s.l.], v. 18, n. 1, p.144-199, 2005.

KOHN, M. Brave new neighborhoods: the privatization of public space. New York: Routledge, 2004.

SOUZA, Marcelo Lopes de; LIPIETZ, Barbara. The 'Arab Spring' and the city. City, [s.1.], v. 15, n. 6, p.618-624, dez. 2011.

MAECKELBERGH, M. Social movements and global governance. In. PARKER, M. et al (ed.). Routledge Companion to Alternative Organization. London: Routledge, 2014. p. 345-358.

MAROM, N. Activising space: the spatial politics of the 2011 protest movement in Israel. Urban Studies, [s.1.], v. 50, n. 13, p.2826-2841, 27 fev. 2013. Disponível em: <http://dx.doi.org/10.1177/0042098013477699>. Acesso em: 8 set. 2016.

MELUCCI, A. Challenging codes: collective action in the information age. Cambridge: Cambridge University Press, 1996.

MINTON, A. What kind of world are we building? The privatization of public space. London: RICS, 2006.

MOUGHTIN, C. Urban design: street and square. 3. ed. Oxford;Burlington: Architectural Press, 2003.

NANCY, J. L. La communauté affronté. Paris: Galillée, 2001.

NANCY, J. L. The innoperative community. Minneapolis: University of Minnesota Press, 1991.

NANCY, J. L. Being singular plural. Stanford: Stanford University Press, 2000.

NANCY, J. L. Communism, the word. In: DOUZINAS, C.; ZIZEK, S. (Ed.). The idea of communism. Londres; Nova York: Verso, 2010.

NANCY, J. L. The creation of the world or globalization. Albany: State University of New York Press, 2007.

NANCY, J. L.; BAILLY, J. C. La comparution. França: Christian Bourgois Éditeur, 1991.

ORS, I. R.. Genie in the bottle: Gezi Park, Taksim Square, and the realignment of democracy and space in Turkey.Philosophy \& Social Criticism, [s.1.], v. 40, n. 4-5, 
p.489-498, 6 mar. 2014. Disponível em:

<http://dx.doi.org/10.1177/0191453714525390>. Acesso em: 7 set. 2016.

Ostaijen van, P. Music hall. Amsterdam: Bert Bakker, 1982.

PATEL, D. Roundabouts and revolutions: public squares, coordination and the diffusion of the arab uprisings. Department of Government: Cornell University, 2013. Rascunho.

SANDE, Mathijs van de. The prefigurative politics of Tahrir Square: an alternative perspective on the 2011 revolutions. Res Publica, [s.1.], v. 19, n. 3, p.223-239, 14 mar. 2013.

SEWELL, W. H. Space in contentious politics. In: AMINZADA, R.; GOLDSTONE, J. E. A. (Ed.). Silence and voice in the study of contentious politics. Cambridge:

Cambridge University Press, 2001.

SHEPARD, B. Occupy Wall Street, social movements, and contested public space. In: SCHIFFMAN, R., BELL, R. Beyond Zuccotti Park: freedom of assembly and the occupation of public space. p. 21-33, Oakland: New Village Press, 2012. p. 21-23.

SMITHSIMON, G. "A stiff clarifying test is in order" occupy and negotiating rights in public space. In: SCHIFFMAN, R.; BELL, R. (Ed.) Beyond Zuccotti Park: freedom of assembly and the occupation of public space. Oakland: New Village Press, 2012. p. 3448.

STAVRIDES, S. Squares in movement. South Atlantic Quarterly, [s.1.], v. 111, n. 3, p.585-596, 1 jul. 2012.

SWYNGEDOUW, Erik. Where is the political? Insurgent mobilisations and the incipient "return of the political". Space and Polity, [s.1.], v. 18, n. 2, p.122-136, 6 mar. 2014. 